\title{
Green Approach in Synthesis of Bio-Inspired Materials
}

\author{
Anamarija Stanković ${ }^{1, *(\mathbb{D})}$, Martina Medvidović-Kosanović ${ }^{1} \mathbb{D}$, Jasminka Kontrec ${ }^{2} \mathbb{D}$ \\ and Branka Njegić Džakula ${ }^{3}$ D
}

1 Institute for General, Inorganic and Physical Chemistry and Teaching Methods in Chemistry, Department of Chemistry, Josip Juraj Strossmayer University of Osijek, Ulica Cara Hadrijana 8/A, 31000 Osijek, Croatia; martina.medvidovic@gmail.com

2 Laboratory for Precipitation Processes, Ruđer Bošković Institute, Bijenička c. 54, 10000 Zagreb, Croatia; Jasminka.Kontrec@irb.hr

3 Ruđer Bošković Institute, Bijenička c. 54, 10000 Zagreb, Croatia; bnjeg@irb.hr

* Correspondence: ster.anamarija@gmail.com

check for updates

Citation: Stanković, A.; MedvidovićKosanović, M.; Kontrec, J.; Džakula, B.N. Green Approach in Synthesis of Bio-Inspired Materials. Crystals 2021, 11, 1243. https://doi.org/10.3390/ cryst11101243

Received: 9 October 2021

Accepted: 13 October 2021

Published: 14 October 202

Publisher's Note: MDPI stays neutral with regard to jurisdictional claims in published maps and institutional affiliations.

Copyright: (c) 2021 by the authors. Licensee MDPI, Basel, Switzerland. This article is an open access article distributed under the terms and conditions of the Creative Commons Attribution (CC BY) license (https:// creativecommons.org/licenses/by/ $4.0 /)$.
In this Special Issue, we focus on biomineralization/pathological biomineralization systems and the synthesis of bioinspired materials. This Special Issue promotes the current trend of "green chemistry", and, as such, in all published papers, only aqueous solutions and eco-friendly additives were used for the production of well-characterized bioinspired materials.

This Special Issue contains four papers: three original research papers and one review. Here, a brief introduction of these papers is provided.

Kontrec et al. [1] in their paper indicate a significant contribution of initial $\mathrm{pH}$ to the overall effect of all parameters relevant to precipitation processes and biomineralization. This paper reports on the influence of initial $\mathrm{pH}$ and type of stirring on the kinetics, phase composition, size, and morphology of spontaneously precipitated calcium carbonate $\left(\mathrm{CaCO}_{3}\right) \cdot \mathrm{CaCO}_{3}$ is one of the most widespread biominerals formed via biomineralization in calcifying organisms. Precipitation processes are the physicochemical basis of biomineralization. The main parameter controlling the precipitation of $\mathrm{CaCO}_{3}$ is supersaturation, but other parameters, such as the concentration of constituent ions and dissolved carbon dioxide $\left(\mathrm{CO}_{2}\right)$ [2], the presence of additives [3,4], temperature [5], $\mathrm{pH}[6]$, ionic strength [7] and hydrodynamics [8], are also known to influence and control $\mathrm{CaCO}_{3}$ precipitation and, consequently, together with the variety of biological constituents and processes, influence biomineralization. Bearing in mind that the supersaturation, ionic strength, and activity ratio of constituent ions $\mathrm{a}\left(\mathrm{Ca}^{2+}\right) / \mathrm{a}\left(\mathrm{CO}_{3}{ }^{2-}\right)$ influence the phase composition and morphology of the precipitated $\mathrm{CaCO}_{3}$, in the work presented in this paper, the initial values of these parameters in all experiments were identical.

Amongst the sixty different types of biominerals, one of the most interesting to humans is calcium phosphate $(\mathrm{CaP})$, the main inorganic component of vertebrate skeletons, and it is also prominent in pathological biomineralization $[9,10]$. The inclusion of additives in the precipitation system affects the rate and mechanism of $\mathrm{CaP}$ formation as well as the properties of the formed solid phase(s). Erceg et al. [11] investigated the influence of different classes of amino acids (AAs), namely, charged (aspartic acid and lysine), polar (asparagine and serine), and non-polar (phenylalanine) amino acids, under conditions similar to physiological conditions. The observed differences in the effects that AAs exert on CaP precipitation, as well as the differences in the behavior of AAs of the same class, indicated that classification based on charge and polarity cannot satisfactorily explain the different effects. Rather, these relatively simple molecules should be studied as specific entities. The obtained results point to the likely complex role of AAs in biological mineralization but also to a rather simple method of controlling CaPs properties, which are of importance in the preparation of multifunctional bone regeneration materials.

Urolithiasis is a multifactorial disease with a high incidence and high recurrence rate, characterized by formation of solid deposits in the urinary tract. Petrović et al. [12] 
have presented in detail an overview of the relevant papers showing that the incidence and prevalence of urolithiasis are constantly increasing, thus presenting an important public health issue, but there is still much to be learned about the stone formation, initial crystallization, and interaction of crystals and epithelial cells. They pointed out that there is a lack of understanding about the bioactive component of plant extracts as well as their safety. Moreover, some plant extracts have been shown to be damaging to the kidneys [13]. Future research should address these issues in order to understand if these therapeutics even reach the kidneys in an in vivo model.

Šafranko et.al. [14] proposed the optimal conditions to obtain the maximum content of the two most dominant calcium oxalate hydrate phases (monohydrate, $\mathrm{CaC}_{2} \mathrm{O}_{4} \bullet \mathrm{H}_{2} \mathrm{O}$, $\mathrm{COM}$, and dihydrate, $\mathrm{CaC}_{2} \mathrm{O}_{4} \bullet 2 \mathrm{H}_{2} \mathrm{O}, \mathrm{COD}$ ) using response surface methodology (RSM). In their study, the influence of temperature, system $\mathrm{pH}$, and the presence of gallic acid on the individual hydrate phase of calcium oxalate formation was investigated. Gallic acid is one of the most abundant phenolic acids, and it is widely distributed throughout the plant kingdom where it is present either in free form or, more commonly, as a constituent of tannins [15]. Regarding its biological activity, gallic acid exerts antibacterial, antiviral, anti-inflammatory, and antioxidant effects [16,17].

By performing statistical analysis, it was observed that a higher temperature, lower system $\mathrm{pH}$, and lower amounts of added gallic acid promoted the formation of the COM hydrate phase of calcium oxalate. However, a lower temperature, higher system $\mathrm{pH}$, and higher amounts of added gallic acid favored the formation of COD. According to the desirability function approach, the optimal conditions for obtaining the maximum content of COM and COD were determined and experimentally verified, showing good agreement with the predicted data with suitable deviations of $\pm 5 \%$. These findings could contribute to efficient process optimization, thereby allowing for specific hydrate phases of calcium oxalate to be obtained while elucidating the possible effects of the operating conditions on crystal formation in the pathological biomineralization of kidney stones.

The editors thank all of the authors who participated in this Special Issue, as well as the reviewers who provided constructive comments on all submissions. We would like to thank the editorial staff at Crystals for their fast and professional handling of all submissions.

Biomineralization/pathological biomineralization is an important and interesting topic, and green synthesis is a novel and exciting direction for bio-inspired material production. We hope that this Special Issue will serve as a useful reference.

Funding: This research received no external funding.

Conflicts of Interest: The authors declare no conflict of interest.

\section{References}

1. Kontrec, J.; Tomašić, N.; Matijaković Mlinarić, N.; Kralj, D.; Njegić Džakula, B. Effect of pH and type of stirring on the spontaneous precipitation of $\mathrm{CaCO}_{3}$ at identical initial supersaturation, ionic strength and $\mathrm{a}\left(\mathrm{Ca}^{2+}\right) / \mathrm{a}\left(\mathrm{CO}_{3}{ }^{2-}\right)$ ratio. Crystals 2021, 11,1075 . [CrossRef]

2. Carlson, C.A.; Bates, N.R.; Hansell, D.A.; Steinberg, D.K. Carbon Cycle. In Encyclopedia of Ocean Sciences; Elsevier: Amsterdam, The Netherlands, 2001; pp. 390-400.

3. Njegić-Džakula, B.; Brečević, L.; Falini, G.; Kralj, D. Calcite crystal growth kinetics in the presence of charged synthetic polypeptides. Cryst. Growth Des. 2009, 9, 2425-2434. [CrossRef]

4. Brečević, L.; Nöthig-Laslo, V.; Kralj, D.; Popović, S. Effect of divalent cations on the formation and structure of calcium carbonate polymorphs. J. Chem. Soc. Faraday Trans. 1996, 92, 1017-1022. [CrossRef]

5. Jie, P.; Zhiming, L. Influence of temperature on microbially induced calcium carbonate precipitation for soil treatment. PLoS ONE 2019, 14, e0218396.

6. Ruiz-Agudo, E.; Putnis, C.V.; Rodriguez-Navarro, C.; Putnis, A. Effect of $\mathrm{pH}$ on calcite growth at constant $\mathrm{aCa}^{2+} / \mathrm{aCO}_{3}{ }^{2-} \mathrm{ratio}$ and supersaturation. Geochim. Cosmochim. Acta 2011, 75, 284-296. [CrossRef]

7. Zuddas, P.; Mucci, A. Kinetics of calcite precipitation from seawater: II. the influence of the ionic strength. Geochim. Cosmochim. Acta 1998, 62, 757-766. [CrossRef]

8. Kralj, D.; Brečević, L.; Nielsen, A.E. Vaterite growth and dissolution in aqueous solution I. Kinetics of crystal growth. J. Cryst. Growth 1990, 104, 793-800. [CrossRef] 
9. Mann, S. Biomineralization: Principles and Concepts in Bioinorganic Materials Chemistry; Oxford Chemistry Masters; Oxford University Press: New York, NY, USA, 2001; ISBN 978-0-19-850882-3.

10. Dorozhkin, S.V. Calcium Orthophosphates. Application in Nature, Biology and Medicine; Pan Stanford Publishing: Singapore, 2012.

11. Erceg, I.; Maltar-Strmečki, N.; Jurašin, D.D.; Strasser, V.; Ćurlin, M.; Lyons, D.M.; Radatović, B.; Mlinarić, N.M.; Kralj, D.; Sikirić, M.D. Comparison of the effect of the amino acids on spontaneous formation and transformation of calcium phosphates. Crystals 2021, 11, 792. [CrossRef]

12. Petrović, A.; Kizivat, T.; Bilić Ćurčić, I.; Smolić, R.; Smolić, M. In vitro cell culture models of hyperoxaluric states: Calcium oxalate and renal epithelial cell interactions. Crystals 2021, 11, 735. [CrossRef]

13. Brown, A.C. Kidney toxicity related to herbs and dietary supplements: Online table of case reports. Part 3 of 5 series. Food Chem. Toxicol. 2017, 107, 502-519. [CrossRef] [PubMed]

14. Šafranko, S.; Goman, S.; Goman, D.; Jokić, S.; Marion, I.D.; Mlinarić, N.M.; Selmani, A.; Medvidović-Kosanović, M.; Stanković, A. Calcium oxalate and gallic acid: Structural characterization and process optimization toward obtaining high contents of calcium oxalate monohydrate and dihydrate. Crystals 2021, 11, 954. [CrossRef]

15. Chu, Y.F.; Sun, J.I.E.; Wu, X.; Liu, R.H. Antioxidant and antiproliferative activities of common vegetables. J. Agric. Food Chem. 2002, 50, 6910-6916. [CrossRef] [PubMed]

16. Kratz, J.M.; Andrighetti-Fröhner, C.R.; Leal, P.C.; Nunes, R.J.; Yunes, R.A.; Trybala, E.; Bergström, T.; Barardi, C.R.M.; Simões, C.M.O. Evaluation of anti-HSV-2 activity of gallic acid and pentyl gallate. Biol. Pharm. Bull. 2008, 31, 903-907. [CrossRef] [PubMed]

17. Kang, M.S.; Oh, J.S.; Kang, I.C.; Hong, S.J.; Choi, C.H. Inhibitory effect of methyl gallate and gallic acid on oral bacteria. J. Microbiol. 2008, 46, 744-750. [CrossRef] [PubMed] 